\title{
Australian Journal of

\section{Genetic diversity of yam (Dioscorea spp.) landrace collections from Ethiopia using simple sequence repeat markers}

\author{
Tewodros Mulualem $^{1,2}$, Firew Mekbib ${ }^{2}$, Hussein Shimelis ${ }^{3}$, Endale Gebre ${ }^{4}$ and Beyene Amelework ${ }^{5 *}$ \\ ${ }^{1}$ Jimma Agricultural Research Center, P.O. Box 192, Jimma, Ethiopia \\ ${ }^{2}$ Haramaya University, School of Plant Sciences, P.O. Box 138, Dire Dawa, Ethiopia \\ ${ }^{3}$ African Centre for Crop Improvement, School of Agriculture, Earth and Environmental Sciences, University of \\ KwaZulu-Natal, Private Bag X01, Scottsville 3209, Pietermaritzburg, South Africa \\ ${ }^{4}$ Ethiopian Institute of Agricultural Research, P.O. Box 2003, Addis Ababa, Ethiopia \\ ${ }^{5}$ Agricultural Research Council, Vegetable and Ornamental Plant, Private Bag X293, Pretoria, 0001, South Africa
}

\section{*Corresponding author: amele_g@yahoo.com OR amelebey@gmail.com}

\begin{abstract}
Yam (Dioscorea spp.) is an important root crop widely used for food, feed and industrial raw material. Knowledge on the genetic diversity present among yam genetic resources is fundamental for variety development and conservation strategies. The objectives of this study were to determine the magnitude and genetic relationship present among yam landrace collections using simple sequence repeat (SSR) markers and to identify genetically unique genotypes for efficient breeding and conservation. Thirty-three yam landraces collected from various regions of Ethiopia were genotyped using 10 selected polymorphic SSR markers. The markers amplified a total of 30 alleles from the population sampled, of which $80 \%$ was polymorphic. The number of alleles detected per locus ranged from 1 to 5, with a mean of 3. Number of effective alleles ranged from 1.00 to 3.57 with a mean of 1.71 . Gene diversity ranged from 0.00 to 0.80 with a mean of 0.53 . The mean polymorphic information content was 0.30 . Genetic distance values ranged from 0.0 to 1.0, with a mean of 0.39. Analysis of molecular variance revealed that $79 \%$ of the variation detected was found within collection sites, while collection sites accounted for only $17 \%$ of the total variation. The study established the existence of considerable genetic diversity among yam landrace collections from Ethiopia. Distinct landraces such as $32 / 83$ and 46/83 from Cluster I and 6/02, 2/87, 3/87, 45/03, 76/02, 21/02 and 34/87 from Cluster II were selected based on their highest dissimilarity index. The selected genetic resources are useful as a source of genes of novelty for yam breeding and variety development.
\end{abstract}

Keywords: Dioscorea spp., genetic diversity, polymorphic information content, simple sequence repeat markers, yam. Abbreviation: ACCI_African Centre for Crop Improvement, AMOVA_Analysis of molecular variance , JARC_ Jimma Agricultural Research Center, $\mathrm{F}_{\mathrm{IS}} \mathrm{S}_{-}$Inbreeding coefficient, $\mathrm{F}_{\mathrm{ST}}$ Genetic differentiation, I_Shannon's information index, He_Gene diversity, Ho_ Observed heterozygosity, $\mathrm{Na}_{-}$Alleles per locus, $\mathrm{Ne}$ _ Number of effective alleles per locus , Nm_ Gene flow, \% $\mathrm{P}_{-}$Percent polymorphism, PIC_Polymorphic information content, SSR_Simple sequence repeat markers, UPGMA_Un-weighted pair group method using arithmetic average.

\section{Introduction}

Globally, approximately $45 \%$ of root and tuber crops are used for food, while the remainder is used for animal feed and industrial raw material (Dansi et al., 2000). Among the tropical tuber crops, yam (Dioscorea spp.) is one of the most important species in Africa (Loko et al., 2015). Yam plays a vital role in ensuring food security and enhancing livelihood systems of millions of people in Africa (Adejumo et al., 2013). In 2014, about 68 million tons of yams (about $97 \%$ of global production) are produced on 7.5 million hectares in sub-Saharan African countries mainly in western Africa (FAOSTAT, 2016). In Ethiopia, Dioscorea species are adapted and widely distributed constituting of both cultivated and wild relatives. The wild progenitor of the major species cultivated in Africa is found in Ethiopia (Terauchi et al., 1992). Ethiopia is believed to be an isolated center of yam cultivation in East Africa (Norman et al., 1995). Yam is becoming an important food security crop in the densely populated areas of South, Southwest, and Western parts of Ethiopia (Norman, 1995; Hildebrand et al., 2002). In these agro-ecologies yam is considered as "insurance" crop against biotic and abiotic stresses and its limited requirement of production inputs makes it a preferred crop in the farming systems (Mulualem, 2012). Production of yam in Ethiopia is dependent on unimproved landraces maintained by farmers. Smallholder farmers maintain considerable genetic diversity that remains to be further exploited for sustainable utilization and conservation of yam genetic resources (Tamiru et al., 2008). Yam is neglected and under researched crop. Consequently, there is little information about genetic diversity of yams and no systematic collection or characterization has been done in Ethiopia. Further, the inherent characters of the crop including polyploidy, dioecy, 
non-synchronous flowering and longer maturity period limited genetic improvement of yam (Tamiru et al., 2015). In most genetic diversity analysis, only agro-morphological or biochemical traits have been used to determine the genetic diversity of Dioscorea species (Dansi et al., 1999). However, these traits are highly influenced by environment and/or genotype $x$ environment interaction effects and may not provide accurate or conclusive genetic classification of the crop. Thus far, yam landraces from Ethiopia were not included into any of the known cultivated Dioscorea species. Therefore, yam genetic resources of the country should be effectively characterized using genomic tools for efficient utilization and conservation. Molecular markers offer several advantages over traditional phenotypic markers, as they provide data that can be analyzed independent of the environmental effects. Molecular markers such as simple sequence repeats (SSRs) (Emmanuel et al., 2015), amplified fragment length polymorphism (AFLP) (Tamiru et al., 2007) and Random Amplified Polymorphic DNA (RAPDs) (Mignouna et al., 2003) have been applied in yams. SSR markers have been increasingly used as the marker of choice in genetic diversity analyses of various crops species owing to their locus specificity, extensive genome coverage, high degree of polymorphism, co-dominant inheritance and amenability for easy automated scoring (Zalapa et al., 2012). Tamiru et al., (2007) characterized 48 yam germplasm collected from Southern Ethiopia using amplified fragment length polymorphism (AFLP) markers. However, the study did not fully included landrace collections from different major yam growing areas of the country. Recently some 38 yam landraces were collected from farmers' fields in Southwest Ethiopia. Based on agro-morphological classification, these landraces are phenotypically distinct (Mulualem, 2016). The genetic diversity and genetic relationships present in these collections from Ethiopia has not been rigorously studied using molecular markers. Therefore, the objectives of the present study were to determine the genetic relationship present among yam landrace collections using simple sequence repeat (SSR) markers and to identify genetically unique genotypes for efficient breeding and conservation.

\section{Results}

\section{Polymorphism and allelic diversity among genotypes}

Ten polymorphic microsatellite primers were used for genetic diversity analysis among 33 landraces collected from Southwest Ethiopia. Overall, 30 putative alleles were detected among the studied landraces. The size of the amplified fragment ranged from 155 to 495 nucleotides. Number of alleles scored per locus varied from 1 (YM13 and YM18) to 5 (YM09) with a mean of 3.0 (Table 3). The number of effective alleles per locus ranged from 1.00 to 3.57 and markers YM18 and YM09 had the lowest and highest numbers of effective alleles. This indicated that intermediate level of genetic diversity among yam landraces from Southwest Ethiopia was present. The gene diversity ranged from 0.00 to 0.80 with a mean of 0.53 (Table 3). Markers YM17 revealed the highest average gene diversity among the ten SSR markers. The polymorphic information content (PIC) values ranged from 0.0 (YM13 and YM18) to 0.72 (YM09), with a mean of 0.30 (Table 3). Although $80 \%$ of the markers were polymorphic, only 4 markers (YM02, YM09, YM12 and YM21) had a PIC values above 0.50 indicating the discriminating ability of these markers. The inbreeding coefficient $\left(F_{I S}\right)$ ranged from 0.0 to 0.78 with a mean of 0.24 (Table 3). Thirty percent of the markers had negative inbreeding coefficient values indicating an excess of heterozygotes. For loci YM02, YM09 and YM12, 71\%, 68\% and $66 \%$ of the genotypes were expected to be heterozygous, respectively at the specific locus under random mating conditions. However, $47 \%, 68 \%$ and $66 \%$ of the genotypes were heterozygotes for YM02, YM09 and YM12, respectively.

\section{Genetic diversity within and between populations}

Table 4 presented the analysis of genetic diversity within and among the 33 yam landraces classified by areas of collection. Shannon's information index ranged from 0.35 to 0.65 with a mean of 0.45 . Percentage of polymorphic loci of genotypes ranged from $40 \%$ to $80 \%$ with the mean of $58.6 \%$. Landraces collected from Sheko District had the highest polymorphic loci, while collections from Kersa District revealed the lowest polymorphic loci. Analysis of molecular variance for these landraces, using collection sites as grouping criteria, was conducted to examine the differences among populations, among individuals and within individual. The AMOVA based on seven populations revealed that the within individual variance accounted for $79 \%(P<0.001)$ of the total variation observed among the landrace collections (Table 5). Conversely, variation among individual within population was $17 \%(\mathrm{P}<0.008)$ and the variation among populations based on collection site contributed only $4 \%$. Among all the seven populations studied, there was nonsignificant variation. According to standard guidelines for the interpretation of genetic differentiation (Wright, 1978), the range 0.0 to 0.005 indicates little, 0.05 to 0.15 moderate, 0.15 to 0.25 great, and above 0.25 very large genetic differentiations. In this study, genetic differentiation ranged from low (0.02) between Yeki and Seka-Chekorsa collection sites to moderate (0.14) between Shebe-Sombo and SekaChekorsa (Table 6). According to Slatkin (1989) and Morjan and Rieseberg (2004), gene flow $<1$ is considered to be low, while $\mathrm{Nm}=1$ is considered to be moderate and $\mathrm{Nm}>1$ is considered to be high. The gene flow ranged from 1.57 to 13.76 with an overall mean of 5.24 (Table 6).

\section{Cluster analysis}

The UPGMA cluster analysis based on genetic dissimilarity using the neighbor-joining method in DARwin 5.0 grouped the 33 landraces into two major clusters (Fig 2). The existence of distinct clusters was also confirmed by the high cophenetic correlation coefficient $(r=0.99)$. Cluster $\mid$ consisted 5 (15.2\%) of the total landraces that formed two Sub-groups IA and IIA with a mean Euclidean distance of 0.51 . The landraces were collected from Jimma (two from Shebe-Sombo and one from Dedo) and Bench Maji (two landraces from Sheko) zones from Southwest Ethiopia. Landraces in Sub-group IA (32/83, 54/02 and 24/02) were distantly related. In Sub-group IIA landraces 10/002 and $46 / 83$ were grouped together. Cluster II composed of three Sub-groups (IB, IIB and IIIB), which consisted of 28 (84.8\%) of the yam landraces evaluated. Among the total landraces, 18 $(54.4 \%), 5(15.2 \%)$ and $5(15.2 \%)$ where collected from 
Jimma, Sheka and Bench Maji zones, respectively. Except two landraces (32/83 and 46/83), all the landraces collected before 1990 were grouped in Cluster II. In Cluster II, Subgroup IIB had the largest number of landraces 22 (66.7\%) with mean Euclidean distance of 0.31, whereas Sub-group IB and IIIB consists of $4(12.1 \%)$ and $2(6.0 \%)$ of the landraces tested, respectively. The majority of old landraces collections were grouped in Sub-group IIB. In the latter Subgroup, the landraces $2 / 87,6 / 02,3 / 87 / 06 / 83,45 / 03 / 39 / 87$, and $76 / 02$ were distantly related to the other landraces. In this Sub-group, landraces $06 / 83$ and $3 / 87 ; 39 / 87$ and $45 / 03$; $7 / 84,37 / 87$ and $08 / 02$; and $60 / 87$ and $06 / 2000$ were closely related. These landraces may have the same genetic makeup but they may be collected under different names at different years.

\section{Discussion}

The SSR primers generated a total of 30 putative alleles of different fragment size ranging from 155 to 495 nucleotides. The number of alleles investigated ranged from 1 to 5 , with a mean value of 3.0 per locus. This result was fairly similar to 2.8 alleles per locus reported by Silva and Gustavo (2006). However, the size of polymorphic bands obtained from this study is greater than the study reported by Abebe et al. (2013) on yam. A greater number of alleles (97) were reported by Obidiegwu et al. (2009) and 45 by Marcos et al. (2012). The number of effective alleles per locus ranged from 1.0 - 3.57 with a mean of 1.71. The number of effective alleles per locus obtained in this study was quite similar to previously reported by Abebe et al. (2013) on yam. Greater number of alleles generated by SSR markers suggests the usefulness of this marker system for genetic diversity analysis and for subsequent selection and conservation of yam. The results of the mean observed and expected gene diversity within landraces were 0.34 and 0.53 , respectively (Table 3). The mean gene diversity recorded in this study was relatively smaller than the values reported by Obidiegwu et al. (2009). The authors studied genetic diversity among 89 water yam (Dioscorea alata L.) landrace collections of West Africa using 13 SSR markers and $67 \%$ of the genotypes were found to be heterozygous. The higher level of allelic diversity of SSR loci found in Obidiegwu et al. (2009) was probably associated with the wide range of genetic diversity represented in the landrace of yams collected from West Africa. Similarly, the high level of gene diversity observed in this study signified that landraces used in this study were collected from a wide range of geographic areas with different levels of selection pressure. Besides, $\mathrm{He}$ et al. (1995) reported a high level of polymorphisms in sweet potato which was fixed through vegetative reproduction and maintained through a high level of gene flow due to selfincompatibility. The high level of gene diversity described in this study may have been probably associated with the outcrossing and self-incompatibility in yams. Besides, vegetative propagation could also have attributed to maintaining the levels of genetic diversity (Ngailo et al., 2016). Polymorphic information content $(\mathrm{PIC})$ and inbreeding coefficient $\left(\mathrm{F}_{\mathrm{IS}}\right)$ are the functions of how heterozygosity is partitioned within and among genotypes, based on differences in allele frequencies. $F_{I S}$ represents the average deviation of the population's genotypic proportions from Hardy-Weinberg equilibrium for a locus and the values ranged from 0 to 1 .
The PIC values of the 10 SSR markers used in this study ranged from 0.00 (YM13 and YM18) to 0.72 (YM09) with a mean of 0.30 . Forty percent of the markers used revealed PIC value above 0.50 implying the high discriminating ability of the SSR markers used for this study; hence the markers can suitably be used in genetic diversity and relationship analysis. The PIC values calculated in the present study were in agreement with the report of Serge et al. (2007). In yam characterization study, Silva et al. (2014) also reported a greater mean PIC value (0.62) than the present estimates. Obidiegwu et al. (2009) found PIC values ranging from 0.30 to 0.82 among Guinea yam landraces evaluated using 13 SSR markers. The $F_{I S}$ values revealed that, three of the 10 loci (YM02, YM09 and YM12) showed excess of the heterozygotes (negative $F_{I S}$ value). It may be due to high outcrossing or mutation at the specific loci. Populations may differ with respect to all aspects of diversity and show variation in the number of alleles, allele distribution and frequency (Rao and Hodgkin, 2002). Variation in population may be attributed to the breeding system of the species and the ecological factors such as latitude, altitude, temperature, and moisture availability and other soil related factors. Interspecific diversity can be as a valuable source as intra-specific diversity for crop improvement (Benson et al., 2013). The value of Shannon's information index from this study was slightly lower than reported by Obidiegwu et al. (2009) and Abebe et al. (2013) with a mean Shannon's information index value of 0.94 and 0.65 , respectively. Similarly, the result of the current study was also by far lower than the finding of Ngailo et al. (2016) who reported the genetic diversity from 0.08 to 1.69 with a mean 1.22. The percentage of polymorphic loci ranged from $40 \%$ for landraces collected from Kersa District to $80 \%$ for landraces from Sheko District. The higher percent of polymorphism in the present study could suggest the extent of genetic diversity among yams landraces collected from eight districts in Southwest Ethiopia. The genetic diversity could partly be attributed to differences in agro-climatic conditions of the collection sites. Analysis of molecular variance revealed that there was a highly significant difference $(p<0.001)$ within and among district of collection. Seventy nine percent of the total genetic variation was attributed to the within collection district variation, while only $17 \%$ of the variation was accounted for the between districts variations. However, the contribution of variation among population was non-significant. Comparable results have been reported in yams (Abebe et al., 2013; Marie et al., 2015) and in sweet potato (Gichuki et al., 2003). Zhigang et al. (2014), on the other hand, reported a much lower variation (23.8\%) within population and a higher variation (76.2\%) among population. According to Veasey et al. (2007) the higher variability observed among landraces could provide some insights to the evolutionary dynamics of yams. The result of the present study revealed the presence of a great intra-specific genetic diversity signifying a fairly-well representative number of collection within a given district may capture the genetic diversity of yam in Southwest Ethiopia. The high within individual variation in this study could mainly be due to evolutionary dynamics and out-crossing nature of yam. Although yam is mainly propagated by storage roots, some authors reported yams to be cross-pollinated and can be reproduced through botanical seed (Okereke, 1977; Akoroda, 1983). According to 
Table 1. Description of the 33 yam landraces used in the study.

\begin{tabular}{|c|c|c|c|c|c|}
\hline Landrace & Zone & District & Latitude & Longitude & Altitude \\
\hline $75 / 02$ & Jimma & Kersa & $07^{0} 40^{\prime} 43 \mathrm{~N}$ & $036^{0} 48^{\prime} 76 \mathrm{E}$ & 1734 \\
\hline $08 / 02$ & Jimma & Kersa & $07^{\circ} 40^{\prime} 46 \mathrm{~N}$ & $036^{\circ} 48^{\prime} 79 E$ & 1740 \\
\hline $76 / 02$ & Jimma & Kersa & $07^{0} 40^{\prime} 64 \mathrm{~N}$ & $036^{\circ} 48^{\prime} 84 \mathrm{E}$ & 1728 \\
\hline $0004 / 07$ & Jimma & Kersa & $07^{\circ} 40^{\prime} 55 \mathrm{~N}$ & $036^{\circ} 48^{\prime} 75 \mathrm{E}$ & 1741 \\
\hline $3 / 87$ & Jimma & Manna & $07^{0} 40^{\prime} 58 \mathrm{~N}$ & $036^{\circ} 48^{\prime} 75 \mathrm{E}$ & 1731 \\
\hline $56 / 76$ & Jimma & Manna & $07^{0} 41^{\prime} 89 \mathrm{~N}$ & $036^{\circ} 48^{\prime} 06 \mathrm{E}$ & 1837 \\
\hline $45 / 03$ & Jimma & Manna & $07^{\circ} 41^{\prime} 86 \mathrm{~N}$ & $036^{\circ} 48^{\prime} 08 \mathrm{E}$ & 1810 \\
\hline $37 / 87$ & Jimma & Manna & $07^{\circ} 41^{\prime} 87 N$ & $036^{\circ} 48^{\prime} 13 E$ & 1940 \\
\hline $34 / 87$ & Jimma & Dedo & $07^{0} 31^{\prime} 37 \mathrm{~N}$ & $036^{0} 53^{\prime} 44 \mathrm{E}$ & 1911 \\
\hline $46 / 83$ & Jimma & Dedo & $07^{0} 31^{\prime} 28 \mathrm{~N}$ & $036^{0} 53^{\prime} 59 \mathrm{E}$ & 1771 \\
\hline 116 & Jimma & Dedo & $07^{0} 31^{\prime} 28 \mathrm{~N}$ & $036^{0} 53^{\prime} 63 \mathrm{E}$ & 1683 \\
\hline $06 / 83$ & Jimma & Dedo & $07^{0} 31^{\prime} 32 \mathrm{~N}$ & $036^{0} 53^{\prime} 64 \mathrm{E}$ & 1692 \\
\hline 07/03 & Jimma & Dedo & $07^{0} 31^{\prime} 50 \mathrm{~N}$ & $036^{0} 53^{\prime} 60 E$ & 1733 \\
\hline $27 / 02$ & Jimma & Seka-Chekorsa & $07^{0} 35^{\prime} 06 \mathrm{~N}$ & $036^{\circ} 41^{\prime} 91 \mathrm{E}$ & 1877 \\
\hline $06 / 2000$ & Jimma & Seka-Chekorsa & $07^{0} 35^{\prime} 43 \mathrm{~N}$ & $036^{\circ} 41^{\prime} 86 \mathrm{E}$ & 1850 \\
\hline $7 / 83$ & Jimma & Seka-Chekorsa & $07^{0} 35^{\prime} 06 \mathrm{~N}$ & $036^{\circ} 41^{\prime} 91 \mathrm{E}$ & 1898 \\
\hline $39 / 87$ & Jimma & Seka-Chekorsa & $07^{0} 35^{\prime} 42 \mathrm{~N}$ & $036^{\circ} 42^{\prime} 94 \mathrm{E}$ & 1885 \\
\hline $21 / 02$ & Jimma & Seka-Chekorsa & $07^{0} 36^{\prime} 48 \mathrm{~N}$ & $036^{\circ} 45^{\prime} 09 E$ & 1785 \\
\hline $32 / 83$ & Jimma & Shebe-Sombo & $07^{0} 26^{\prime} 74 \mathrm{~N}$ & $036^{0} 24^{\prime} 01 \mathrm{E}$ & 1372 \\
\hline $24 / 02$ & Jimma & Shebe-Sombo & $07^{0} 26^{\prime} 75 \mathrm{~N}$ & $036^{0} 24^{\prime} 07 E$ & 1379 \\
\hline $2 / 87$ & Jimma & Shebe-Sombo & $07^{0} 26^{\prime} 76 \mathrm{~N}$ & $036^{0} 24^{\prime} 12 \mathrm{E}$ & 1365 \\
\hline $6 / 02$ & Bench Maji & Sheko & $06^{0} 59^{\prime} 66 \mathrm{~N}$ & $035^{\circ} 34^{\prime} 11 \mathrm{E}$ & 1728 \\
\hline $54 / 02$ & Bench Maji & Sheko & $07^{\circ} 02^{\prime} 03 \mathrm{~N}$ & $035^{\circ} 32^{\prime} 77 \mathrm{E}$ & 1892 \\
\hline $10 / 002$ & Bench Maji & Sheko & $07^{\circ} 02^{\prime} 91 \mathrm{~N}$ & $035^{\circ} 29^{\prime} 76 \mathrm{E}$ & 1668 \\
\hline $15 / 2000$ & Bench Maji & Sheko & $07^{0} 04^{\prime} 13 \mathrm{~N}$ & $035^{\circ} 37^{\prime} 74 \mathrm{E}$ & 1320 \\
\hline $57 / 76$ & Bench Maji & Sheko & $07^{\circ} 02^{\prime} 88 \mathrm{~N}$ & $035^{\circ} 29^{\prime} 74 \mathrm{E}$ & 1654 \\
\hline $7 / 84$ & Bench Maji & Sheko & $07^{\circ} 02^{\prime} 88 \mathrm{~N}$ & $035^{\circ} 29^{\prime} 74 \mathrm{E}$ & 1661 \\
\hline $06 / 2001$ & Bench Maji & Sheko & $06^{0} 59^{\prime} 69 \mathrm{~N}$ & $035^{\circ} 34^{\prime} 09 E$ & 1387 \\
\hline $01 / 75$ & Sheka & Yeki & $07^{0} 11^{\prime} 30 \mathrm{~N}$ & $035^{\circ} 26^{\prime} 22 \mathrm{E}$ & 1171 \\
\hline $17 / 02$ & Sheka & Yeki & $07^{0} 11^{\prime} 27 \mathrm{~N}$ & $035^{\circ} 26^{\prime} 26 \mathrm{E}$ & 1176 \\
\hline $58 / 02$ & Sheka & Yeki & $07^{0} 11^{\prime} 22 \mathrm{~N}$ & $035^{\circ} 26^{\prime} 25 \mathrm{E}$ & 1192 \\
\hline $60 / 87$ & Sheka & Yeki & $07^{0} 11^{\prime} 72 \mathrm{~N}$ & $035^{\circ} 26^{\prime} 48 \mathrm{E}$ & 1199 \\
\hline $7 / 85$ & Sheka & Yeki & $07^{0} 14^{\prime} 30 \mathrm{~N}$ & $035^{\circ} 26^{\prime} 17 \mathrm{E}$ & 1173 \\
\hline
\end{tabular}

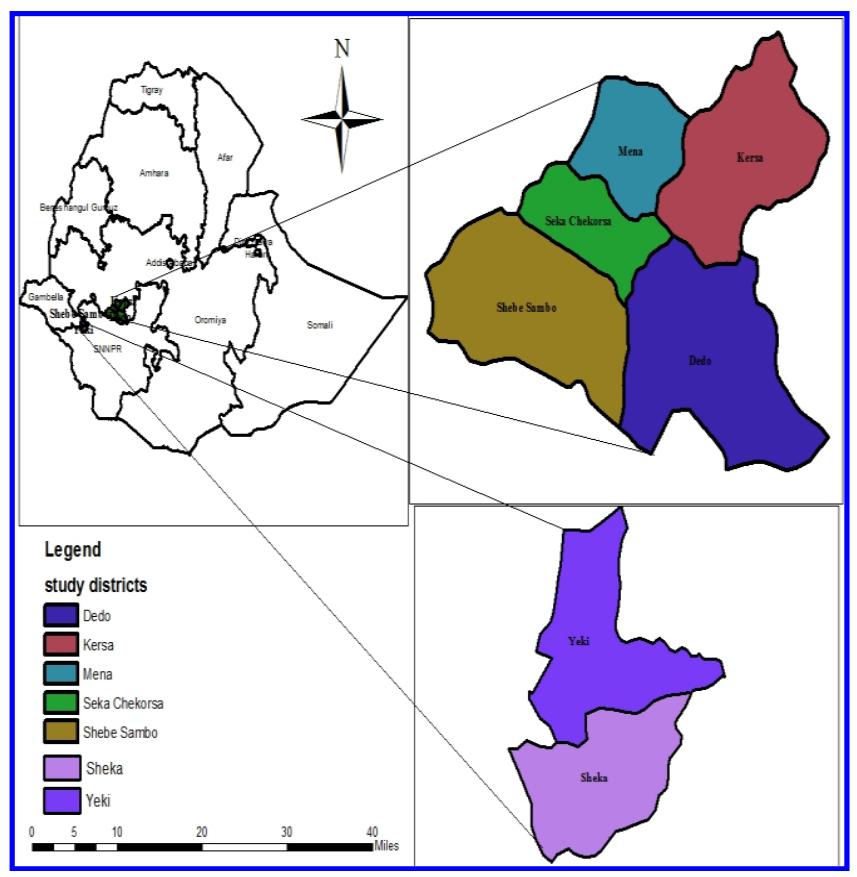

Fig 1. Administrative map of Ethiopia showing five districts where the landraces were collected. 
Table 2. Selected SSR primers for yam genetic diversity study.

\begin{tabular}{|c|c|c|c|c|c|c|}
\hline \multirow[t]{2}{*}{ Locus } & \multirow{2}{*}{$\begin{array}{c}\text { Repeat } \\
\text { motif }\end{array}$} & \multirow{2}{*}{$\begin{array}{l}\text { Forward primer }\left(5^{\prime} \rightarrow 3^{\prime}\right)(\mathrm{F}) \text { and reverse primers } \\
\qquad\left(3^{\prime} \rightarrow 5^{\prime}\right)(\mathrm{R})\end{array}$} & \multirow[t]{2}{*}{ Tem ${ }^{0} \mathrm{C}$} & \multicolumn{2}{|c|}{ GC (\%) } & \multirow{2}{*}{$\begin{array}{l}\text { Expected product } \\
\text { size }\end{array}$} \\
\hline & & & & $F$ & $R$ & \\
\hline \multirow[t]{2}{*}{ YM02 } & $(\mathrm{AAG})_{6}$ & F: TAGATTTCGCTTTTCCACTAGC & 58 & 41 & 41 & 263 \\
\hline & & R: CCTAATCATCATCATCGTCATC & & & & \\
\hline \multirow[t]{2}{*}{ YM03 } & $(\mathrm{GAT})_{6}$ & F: TCACTCAAACAATGAGCGTAG & 60 & 58 & 58 & 202 \\
\hline & & R: GATGGCTGCTGCATGACTG & & & & \\
\hline \multirow[t]{2}{*}{ YM05 } & $(\mathrm{AAG})_{8}$ & F: AGGATTATCACTGAAAGGGCT & 57 & 43 & 43 & 140 \\
\hline & & R: CCTTCCAATTACTCTCCAAGA & & & & \\
\hline \multirow[t]{2}{*}{ YM09 } & $(\mathrm{CTT})_{12}$ & F: AGGAACATTCCCACTCAGTTA & 59 & 43 & 53 & 193 \\
\hline & & R: ATTGGGCAAGTGTGGTGTG & & & & \\
\hline \multirow[t]{2}{*}{ YM12 } & $\mathrm{AAC})_{8}$ & F: TGAGCATTCTTGTTTTGCCG & 60 & 45 & 61 & 215 \\
\hline & & R: CTTTCAGGGCGTGCATGG & & & & \\
\hline \multirow[t]{2}{*}{ YM13 } & $(\mathrm{CTT})_{8}$ & F: CCAATCACATCACGTCTAGTC & 57 & 45 & 45 & 328 \\
\hline & & R: GACAATAGAAACTTCGAGACC & & & & \\
\hline \multirow[t]{2}{*}{ YM15 } & $(\mathrm{CTT})_{7}$ & F: CСАTCTCCTCCСТTATCTACAC & 57 & 50 & 45 & 485 \\
\hline & & R: GGGATTGAAGTTCCAGAGACT & & & & \\
\hline \multirow[t]{2}{*}{ YM17 } & $(\mathrm{AC})_{8}$ & F: TCCCTCAATTAAAGCATAGCC & 60 & 43 & 50 & 181 \\
\hline & & R: AGCCACCAAACATCTTGCTC & & & & \\
\hline \multirow[t]{2}{*}{ YM18 } & $(\mathrm{GT})_{19}$ & F: GACATTGGGGATCTCTTATCA & 57 & 41 & 41 & 266 \\
\hline & & R: TAGCAGCAGTAACGTTAAGGA & & & & \\
\hline \multirow[t]{2}{*}{ YM21 } & $(\mathrm{GAT})_{5}$ & F: AATGATGCATCTGAGGATAGT & 57 & 41 & 41 & 340 \\
\hline & & R: GATGCTATTACGACAACCTTG & & & & \\
\hline
\end{tabular}

Sources: Tamiru et al. 2015.

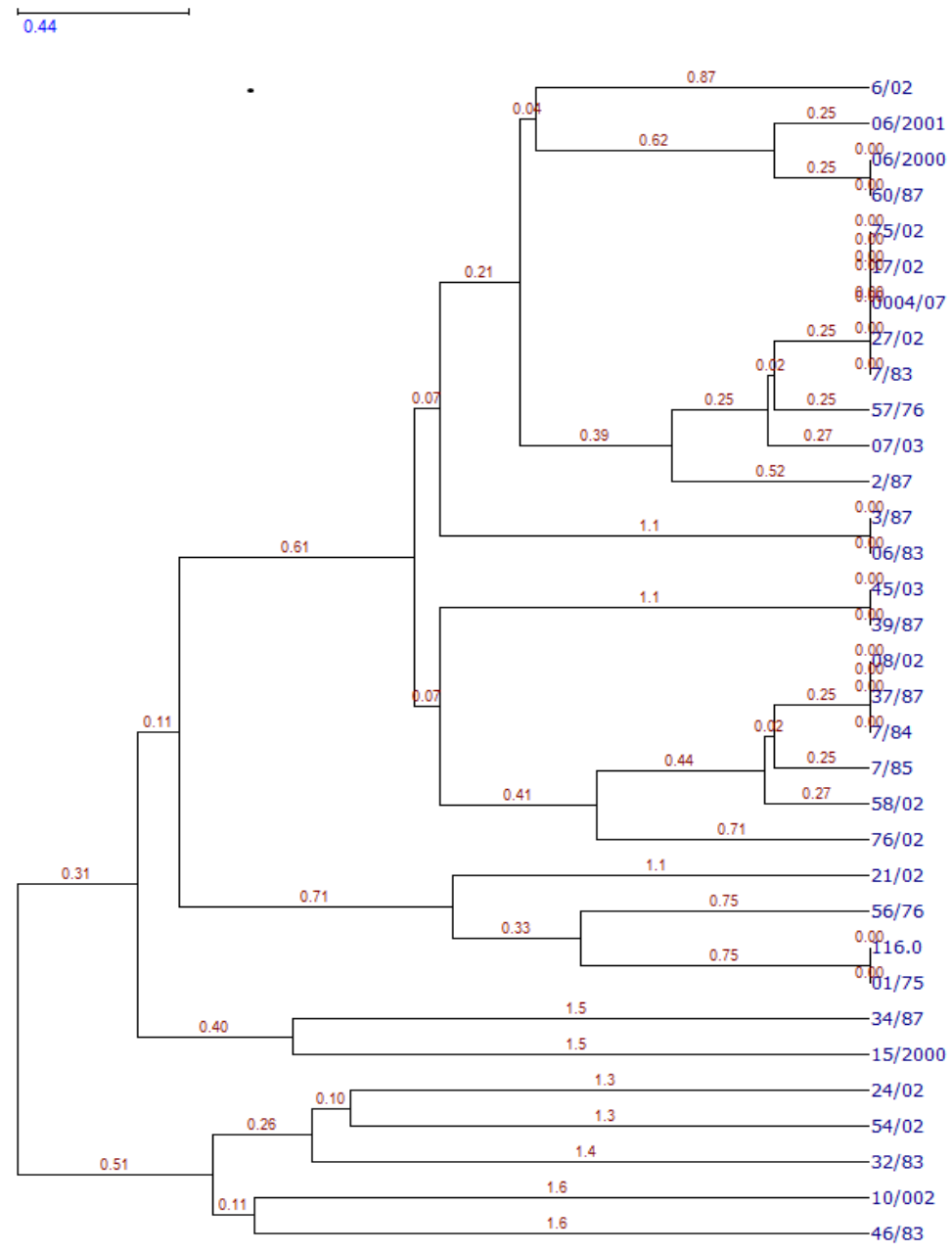

Fig 2. Dendrogram revealing genetic relationships among 33 yam landraces from South west Ethiopia based on SSR analysis of Euclidian similarity coefficients with UPGMA clustering. 
Table 3. Genetic diversity within and among 33 yam landraces based on 10 SSR markers.

\begin{tabular}{llllllll}
\hline Locus & \multicolumn{7}{c}{ Genetic parameter } \\
\cline { 2 - 7 } & $\mathrm{N}_{\mathrm{a}}$ & OFS (bp) & $\mathrm{N}_{\mathrm{e}}$ & $\mathrm{H}_{\mathrm{o}}$ & $\mathrm{H}_{\mathrm{e}}$ & $F_{I S}$ & $\mathrm{PIC}$ \\
\hline YM02 & 3 & $237-242$ & 2.22 & 0.71 & 0.47 & -0.29 & 0.55 \\
YM03 & 4 & $214-235$ & 1.13 & 0.03 & 0.74 & 0.74 & 0.12 \\
YM05 & 2 & $155-158$ & 1.10 & 0.10 & 0.74 & 0.05 & 0.09 \\
YM09 & 5 & $201-225$ & 3.57 & 0.68 & 0.65 & -0.06 & 0.72 \\
YM12 & 4 & $221-232$ & 2.34 & 0.70 & 0.66 & -0.22 & 0.57 \\
YM13 & 1 & 319 & 1.00 & 0.00 & 0.00 & 0.00 & 0.00 \\
YM15 & 3 & $491-495$ & 1.19 & 0.03 & 0.79 & 0.78 & 0.16 \\
YM17 & 4 & $192-211$ & 1.41 & 0.30 & 0.80 & 0.05 & 0.29 \\
YM18 & 1 & 256 & 1.00 & 0.00 & 0.00 & 0.00 & 0.00 \\
YM21 & 3 & $368-373$ & 2.14 & 0.89 & 0.40 & 0.67 & 0.53 \\
Mean & 3.00 & - & 1.71 & 0.34 & 0.53 & 0.24 & 0.30 \\
SE & 0.42 & - & 0.27 & 0.11 & 0.10 & 0.12 & 0.08 \\
\hline
\end{tabular}

Where, $\mathrm{N}=$ Total number of alleles per locus, $\mathrm{OFS}=$ Observed fragment size, $\mathrm{K}=$ Expected heterozygosity, $\mathrm{N}_{\mathrm{e}}=$ Number of effective alleles per locus, $\mathrm{H}_{\mathrm{o}}=\mathrm{Observed}$ gene diversity within landraces, Where, $\mathrm{N}=$ Total number of alleles per locus, $\mathrm{OFS}=$ Observed fragment size, $\mathrm{K}=$ Expected heterozygosity, $\mathrm{N}_{\mathrm{e}}=$ Number of effective all
$\mathrm{H}_{\mathrm{e}}=$ Average gene diversity within landraces, $\mathrm{F}_{\mathrm{IS}}=$ Inbreeding coefficient, $\mathrm{PIC}=$ Polymorphic information content and $\mathrm{SE}=$ Standard error.

Table 4. Genetic diversity within and among the 33 yam landraces classified by areas of collection.

\begin{tabular}{lllllllll}
\hline District & \multicolumn{7}{c}{ Genetic parameter } \\
\cline { 2 - 9 } & $\mathrm{N}$ & $\mathrm{N}_{\mathrm{a}}$ & $\mathrm{N}_{\mathrm{e}}$ & $\mathrm{I}$ & $\mathrm{H}_{\mathrm{o}}$ & $\mathrm{H}_{\mathrm{e}}$ & $\mathrm{F}_{\mathrm{IS}}$ & $\% \mathrm{P}$ \\
\hline Dedo & 5 & 2.3 & 1.83 & 0.6 & 0.34 & 0.41 & 0.13 & 70.0 \\
Kersa & 4 & 1.6 & 1.53 & 0.35 & 0.4 & 0.26 & -0.8 & 40.0 \\
Manna & 4 & 1.7 & 1.51 & 0.38 & 0.3 & 0.28 & -0.29 & 50.0 \\
Seka-Chekorsa & 5 & 1.9 & 1.48 & 0.39 & 0.34 & 0.26 & -0.37 & 60.0 \\
Shebe-Sombo & 3 & 2.1 & 1.69 & 0.47 & 0.33 & 0.3 & -0.23 & 60.0 \\
Sheko & 7 & 2.2 & 1.9 & 0.65 & 0.37 & 0.55 & 0.08 & 80.0 \\
Yeki & 5 & 1.7 & 1.45 & 0.35 & 0.33 & 0.25 & -0.45 & 50.0 \\
Mean & 4.71 & 1.93 & 1.63 & 0.45 & 0.34 & 0.33 & -0.22 & 58.6 \\
SE & 0.15 & 0.11 & 0.08 & 0.05 & 0.04 & 0.04 & 0.06 & 5.1 \\
\hline$=$ Number of individual within each population, Na= total number of alleles per locus, Ne= number of effective alleles per locus, I= Shannon's information index, Ho= observed gene diversity
\end{tabular}

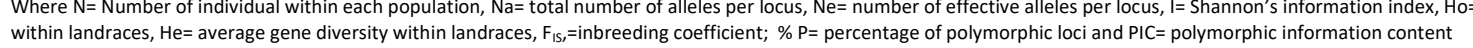

Table 5. Analysis of molecular variance (AMOVA) among the 33 yam landraces collected from seven districts using 10 SSR markers.

\begin{tabular}{lcccccc}
\hline Source & $\mathrm{df}$ & $\mathrm{SS}$ & $\mathrm{MS}$ & $\begin{array}{c}\text { Estimated } \\
\text { variance }\end{array}$ & $\begin{array}{c}\text { Percentage } \\
\text { variation }\end{array}$ & F-Statistics \\
\hline Among populations & 6 & 18.239 & $3.040^{\text {ns }}$ & 0.082 & $4 \%$ & 0.060 \\
Among individual & 26 & 59.125 & $2.274^{* *}$ & 0.342 & $17 \%$ & 0.008 \\
Within individual & 33 & 52.500 & $1.591^{* *}$ & 1.591 & $79 \%$ & $<0.001$ \\
\hline Total & 65 & 129.864 & & 2.015 & $100 \%$ & \\
\hline df= Degree of freedom, SS= sum of squares, MS= mean sum of squares
\end{tabular}

Table 6. Pair-wise estimates of gene flow $\left(\mathrm{N}_{\mathrm{m}}\right)$ (above diagonal) and genetic differentiation $\left(\mathrm{F}_{\mathrm{ST}}\right)$ (lower diagonal).

\begin{tabular}{|c|c|c|c|c|c|c|c|}
\hline \multirow[b]{2}{*}{ District } & \multicolumn{7}{|c|}{ Gene Flow $\left(\mathrm{N}_{\mathrm{m}}\right)$} \\
\hline & Dedo & Kersa & Manna & $\begin{array}{l}\text { Seka- } \\
\text { Chekorsa }\end{array}$ & Sheko & $\begin{array}{l}\text { Shebe- } \\
\text { Sombo }\end{array}$ & Yeki \\
\hline Dedo & & 2.852 & 3.852 & 3.652 & 4.282 & 2.479 & 2.999 \\
\hline Kersa & 0.081 & & 3.078 & 6.368 & 7.942 & 1.766 & 5.883 \\
\hline Manna & 0.061 & 0.075 & & 7.242 & 6.99 & 1.572 & 4.979 \\
\hline Seka-Chekorsa & 0.064 & 0.038 & 0.033 & & 13.452 & 2.053 & 13.762 \\
\hline Sheko & 0.055 & 0.031 & 0.035 & 0.018 & & 2.485 & 9.812 \\
\hline Shebe-Sombo & 0.092 & 0.124 & 0.137 & 0.109 & 0.091 & & 1.994 \\
\hline \multirow[t]{2}{*}{ Yeki } & 0.077 & 0.041 & 0.048 & 0.018 & 0.025 & 0.111 & \\
\hline & \multicolumn{7}{|c|}{ Genetic differentiation $\left(F_{S T}\right)$} \\
\hline
\end{tabular}


Obidiegwu et al. (2009), yams are dioecious plants and spontaneous hybridization may have contributed to the ancestry of some landrace. Traditionally, the selection of somatic mutants might have been the main source of variability used by farmers. The lower variance among populations of this study can also be explained by the low differentiation (0.04 \pm 0.16$)$ and high gene flow (1.57 to 13.45) observed among districts. It could further be elucidated by exchange of yam landrace among nearby districts through farmers and traders that may enhance gene flow across regions of Southwest Ethiopia.

Genetic clustering of the 33 landraces through the SSR markers classified the landraces into two distinct clusters. A cophenetic correlation coefficient $(r=0.99)$ was observed indicating a distinct clustering structure. However, the cluster patterns did not correspond to the predefined population structure based on the districts of collection. This may be due to the fact that landraces collected from similar zone/districts belong to the same gene pool or they may have similar ancestral relationship. In the present study, landraces collected from geographic location with wide range of variation were grouped together in the same cluster. These results are in agreement with earlier studies which reported that geographical separation did not affect genetic distance among genotypes (Zhang et al., 2012). Ganesamurthy et al. (2010) indicated that geographic location should not be used as a measure of genetic diversity during selection of crops. This could be a consequence of exchange of genetic materials among the neighboring farmers as well as traders in the region. Besides, farmers' selections and management practice affect the patterns of genetic diversity (Barnaud et al., 2008). In yams, storage roots are used as a propagating material in the following planting season, which in turn increases the genetic similarity among landraces. Mekbib (2007) reported that farmers selected and preserved landraces on the basis of the phenotypic and agronomic traits.

\section{Materials and Methods}

Plant materials, DNA extraction, SSR amplification and Polymerase chain reaction (PCR)

A total of 33 yam landraces were collected from seven districts of Jimma, Sheka and Bench-Maji Zones of Southwest Ethiopia. The list of 33 yam landraces that represented distinct phenotypic variation and their area of collections is presented in Table 1 and Fig 1 . The landraces were grown at Jimma Agricultural Research Center, Ethiopia. DNA samples of the yam landraces were collected on Whatman Flinders Technology Associates (FTA ${ }^{\mathrm{TM}}$ ) cards three weeks after planting. The FTA cards were labeled prior to sampling. Individual leaf was excised from the plant, wrapped round the FTA paper strip, and leaf sample extract were pressed on to the FTA paper until both sides of the FTA were soaked with leaf sap. To prevent cross contamination in between samples, $70 \%$ of ethanol was used for cleaning materials. The sap was extracted from healthy leaves of five plants per genotype. Genotyping was conducted at Incotec Biotechnology laboratory, South Africa. All samples were used in bulk amplification, using DNA from five individual plants. A single punch of each card per submission was taken and homogenized in the Finnzymes dilution buffer. Two micro-liters of each bulked sample were used in the polymerase chain reaction (PCR).

PCR amplification reaction contained $20 \mu \mathrm{l}$ of PCR mix (1X PCR buffer, $3 \mathrm{mM} \mathrm{MgCl}, 1.25 \mathrm{U}$ Taq polymerase, $0.2 \mathrm{mM}$ dNTPs, $4 \mathrm{pM}$ each primer) and 2 FTA disc or $5 \mu$ of CTAB extracted gDNA. A PCR profile of initial denaturation for 2 min at $94{ }^{\circ} \mathrm{C}$, and 33 cycles of denaturation for $1 \mathrm{~min}$ at 94 ${ }^{\circ} \mathrm{C}$, annealing temperature of $63{ }^{\circ} \mathrm{C}$ for $2 \mathrm{~min}$, extension for 2 min at $72{ }^{\circ} \mathrm{C}$ was used. The PCR products were fluorescently labeled and separated by capillary electrophoresis on an ABI 3013 automatic sequencer (Applied Biosystems, Johannesburg, South Africa); analysis was performed using GeneMapper 4.1. A total of ten polymorphic SSR markers were used for this study (Table 2). The markers were selected based on their polymorphic information content (Tamiru et al., 2015)

\section{Data analysis}

Genotypic data were subjected to analyses with various measures of genetic diversity within and among genotypes using GenAlex software version 6.5 (Peakall and Smouse, 2006). The analysis of genotypic data in this study was performed using two approaches. In the first approach, polymorphisms were treated as binary data (presence or absence). In this case, each amplified fragment was considered as one locus and evaluated as dominant markers. However, to determine the genetic structure within and among genotypes, a second approach based on the codominant nature of the marker was adopted.

The $\chi^{2}$ test was performed to determine the differences in allele frequencies among the SSR markers. Genetic diversity parameters such as total number of alleles per locus $\left(N_{a}\right)$, number of effective alleles per locus $\left(N_{e}\right)$, Shannon's information index $(\mathrm{I})$, observed heterozygosity $\left(\mathrm{H}_{\mathrm{o}}\right)$, gene diversity $\left(\mathrm{H}_{\mathrm{e}}\right)$, percent polymorphism $(\% \mathrm{P})$, and inbreeding coefficient $\left(F_{\mid S}\right)$ were determined using the protocol of Nei and $\mathrm{Li}$ (1979). Other parameters such as differentiation, gene flow $\left(\mathrm{N}_{\mathrm{m}}\right)$ and polymorphic information content (PIC) were estimated using GenAlex software. Based on Jaccards distances, analysis of molecular variance (AMOVA) was conducted using GenAlex software to partition total genetic variation into within and among districts of genotype collection so as to quantify the level of diversity and genetic relationship among landraces.

The binary data scored as either presence or absence of the band for the 33 yam landraces were used for cluster analysis. Cluster analysis was done based on neighbor joining algorithm using un-weighted pair group method using arithmetic average (UPGMA) in DARwin 5.0 software (Perrier and Jacquemoud-Collet, 2006). A dendrogram was then generated on the dissimilarity matrix. Bootstrap analysis was performed for node construction using 10,000 bootstrap values to estimate the liability of the clustering pattern. The distinctiveness of the different clusters was checked by cophenetic correlation coefficient.

\section{Conclusion}

The SSR markers revealed wide genetic divergence among the yam landraces studied. The cluster analyses grouped the 33 landraces into two distinct clusters irrespective of the areas of collection. Landraces $06 / 83$ and $3 / 87 ; 39 / 87$ and 
$45 / 03 ; 7 / 84,37 / 87$ and $08 / 02$; and $60 / 87$ and $06 / 2000$ showed close genetic relationship suggesting may have the same genetic makeup but they may be collected under different names at different years. Thirty percent of the evaluated landraces were found to be distantly related. Landraces 6/02, 2/87, 3/87, 45/03, 76/02, 21/02, 34/87, $32 / 83$ and $46 / 83$ were identified as genetically diverse landraces. These can be used as source of novel genes of in yam breeding programs. Information generated in this study would be valuable for breeding and conservation strategies of yams.

\section{Acknowledgment}

Jimma Agricultural Research Center (JARC) and African Centre for Crop Improvement (ACCl) are acknowledged for financial and technical support of this study. Dr. Muluneh Tamiru, Iwate Biotechnology Institute/Iwate Biotechnology Research, Japan is also acknowledged for his technical support.

\section{References}

Abebe W, Demissew S, Fay MF, Smith RJ, Nordal I, Wilkin P (2013) Genetic diversity and population structure of Guinea yams (Dioscorea spp.) and their wild relatives in South and Southwest Ethiopia as revealed by microsatellite markers. Genet Res Crop Evol 60: 529-541.

Adejumo BA, Okundare B, Balogun SA (2013) Quality attributes of yam flour (Elubo) as affected by blanching water temperature and soaking time. Int J Engin Sci 2: 216221.

Akoroda MO (1983) Floral biology in relation to hand pollination of white yam Dioscore arutundata. Euphytica 32, 831-838.

Barnaud A, Trigueros G, McKey D, Joly HI (2008) High outcrossing rates in fields with mixed sorghum landraces: how are landraces maintained? Heredity 101: 445-452.

Benson ON, Beatrice AW, Samuel G, Otto GD, Augustino OO (2013) Genetic diversity in cultivated sesame and related wild species in East Africa. J Crop Sci Biotech 16: 9-15.

Dansi A, Mignouna HD, Asiedu R, Quin FM (1999) Morphological diversity, cultivar groups and possible descent in the cultivated yams (Dioscore acayenensis /D. rotundata complex) in Benin Republic. Genet Res Crop Evol 46: 371-388.

Dansi A, Mignouna HD, Zoundjih J, Sangare A, Asied R, Ahoussou N (2000) Using isozyme polymorphism to assess genetic variation within cultivated yams (D. cayenensis/ rotundata complex) of the Republic of Benin. Genet Res Crop Evol 47: 371-383.

Emmanuel O, Michael A, Asare PA, Tetteh JP (2015) Molecular categorization of some water yam (Dioscore aalata L.) germplasm in Ghana using microsatellite (SSR) markers. J Agric Sci 7: 225-234.

Ganesamurthy K, Punitha D, Elangovan M (2010) Genetic diversity among the land races of sorghum collected in Tamil Nadu. Electr. J Plant Breed 1: 1375-1379.

Gichuki ST, Bonte L, Burg D, Kapinga K, Simon R (2003) Genetic diversity in sweet potato [Ipomea batatas (L.) Lam] in relationship to geographic sources as assessed with RAPD markers. Genet Res Crop Evol 50: 429-437.
He G, Prakash C, Jarret R (1995) Analysis of genetic diversity in a sweet potato (Ipomoea batatas) germplasm collection using DNA amplification fingerprinting. Genome 38: 938945.

Hildebrand EA, Demissew S, Wilkin P (2002) Local and regional landrace disappearance in species of Dioscorea $\mathrm{L}$. (yams) in Southwest Ethiopia. In: Hildebrand EA, Sebsebe $D$, Wilkin $P$ (eds.) Proceeding of the $7^{\text {th }}$ international congress of ethno- biology. University of Georgia press 717.

Loko YL, Adjatin A, Dansi A, Vodouhe R, Sanni A (2015) Participatory evaluation of Guinea yam (Dioscore acayenensis Lam. D. rotundata Poir. complex) landraces from Benin and agro-morphological characterization of cultivars tolerant to drought, high soil moisture and chips storage insects. Genet Res Crop Evol 62: 1181-1192.

Marcos VB, Gabriel D, Mike A, José C, Elizabeth A (2012) DNA fingerprinting of water yam (Dioscore aalata) cultivars in Brazil based on microsatellite markers. Hortic Bras 30: 653-659.

Marie FSN, Ngwe DNO, Simon J (2015) Evolution and phylogenetic diversity of yam species (Dioscorea spp.): Implication for conservation and agricultural practices. PLoS one 10: 1-13.

Mekbib F (2007) Infra-specific folk taxonomy in sorghum [Sorghum bicolor (L.) Moench] in Ethiopia: folk nomenclature, classification, and criteria. J Ethno Biol Ethno Med 3: 1746-4269.

Mignouna HD, Abang MM, Fagbemi SA (2003) A comparative assessment of molecular markers assays (AFLP, RAPD and SSR for white yam (Dioscore arutundata Poir) germplasm characterization. Ann Appl Biol 142: 269276.

Morjan CL, Rieseberg LH (2004) How species evolve collectively: Implications of gene flow and selection for the spread of advantageous alleles. Mol Ecol 13: 1341-1356.

Mulualem TB (2012) Production and post-harvest system of yam (Dioscorea spp.). Lambert Academic Publishing, Germany.

Mulualem T (2016) Genetic diversity, path coefficient analysis, classification and evaluation of yams (Dioscorea spp.) in Southwest Ethiopia. Ph.D. Thesis, Haramaya University. Ethiopia.

Nei M, Li W (1979) Mathematical method for studying genetic variation in terms of restriction endonucleases. Proc. Natl. Acad. Sci. 76: 5256 -5273.

Ngailo S, Shimelis H, Sibiya J, Amelework B, Mtunda K (2016) Genetic diversity assessment of Tanzanian sweet potato genotypes using simple sequence repeat markers. S. Afr J Bot. 102: 40-45.

Norman MJT, Pearson CJ, Searle PGE (1995) The ecology of tropical foods crops, second edition. Cambridge University Press, UK.

Obidiegwu JE, Kolesnikova M, Eneobong EE, Muoneke CO, Asiedu R (2009) SSR markers reveal diversity in Guinea yam (Dioscore acayenensis/D. rotundata) core set. Afr J Biotechnol 8: 2730-2739.

Peakall R, Smouse PE (2012) Genetic analysis in excel. Population genetic software for teaching and research. Bioinformatics 28: 2537-2539.

Perrier X, Jacquemoud-Collet JP (2006) DARwin software. Dissimilarity Analysis and Representation for Windows. Available from http://www.darwin.cirad.fr/darwin.html. 
Rao VR, Hodgkin T (2002) Genetic diversity and conservation and utilization of plant genetic resources. Plant Cell Tissue Organ Cult 68: 1-19.

Silva B, Gustavo B (2006) Molecular characterization of Colombian yam germplasm by selective amplification of microsatellite polymorphic loci. Rev Colomb Biotecnol 8: 60-66.

Silva LR, Bajay MM, Monteiro M, Mezette TF, Nascimento WF, Zucchi MI, Pinheiro JB, Veasey EA (2014) Isolation and characterization of microsatellites for the yam Dioscore acayenensis (Dioscore aceae) and cross-amplification in $D$. rotundata. Genet Mol Res 13: 2766-2771.

Slatkin M (1989) Detecting small amounts of gene flow from phylogenies of alleles. Genetics 12: 609-612.

Tamiru M, Heiko C, Becker H, Maass L (2007) Genetic diversity in yam germplasm from Ethiopia and their relatedness to the main cultivated Dioscorea species assessed by AFLP markers. J. Crop Sci 47: 1744-1753.

Tamiru M, Heiko C, Becker B, Maass L (2011) Comparative analysis of morphological and farmers' cognitive diversity in yam landraces (Dioscorea spp.) from Southern Ethiopia. Trop Agric Dev 55: 28-43.
Tamiru M, Yamanaka S, Mitsuoka C, Babil P, Takagi H, LopezMontes A, Sartie A, Asiedu R, Terauchi R (2015) Development of genomic simple sequence repeats markers for yam. Crop Sci 55: 2191-2200.

Terauchi R, Chikaleke VA, Thottappilly G, Hahn SK (1992) Origin and phylogeny of Guinea yams as revealed by RFLP analysis of chloroplast DNA and nuclear ribosomal DNA. Theor Appl Genet 83: 743-751.

Veasey EA, Silva JRQ, Rosa MS, Borges A, Bressan EA, Peroni $N$ (2007) Phenology and morphological diversity of sweet potato landraces The Vale Do Ribeira. Scient Agric 64: 416427.

Wright S (1978) Evolution and the genetics of populations: Variability within and among natural populations. University of Chicago Press, Chicago, USA.

Zalapa JE, Cuevas H, Zhu H, Steffan S, Senalik D, Zeldin E, McCown B, Harbut R, Simon P (2012) Using next generation sequencing approaches to isolate simple sequence repeat (SSR) loci in the plant sciences. Amer J Bot 99: 193-208.

Zhang H, Wei L, Miao H, Zhang T, Wang C (2012) Development and validation of genetic SSR markers in sesame by RNA-seq. BMC Genomics 13: 316-317.

Zhigang $W$, Wu J, Xiao X, Zheng $M$, Chuan $Y$, Xin C, Nitin M (2014) Genetic diversity analysis of yams (Dioscorea spp.) cultivated in China using ISSR and SRAP markers. Genet Res Crop Evol 61: 639-650. 